\title{
PENGARUH LABEL HALAL DIMODERASI RELIGIUSITAS TERHADAP KEPUTUSAN PEMBELIAN PRODUK KEMASAN OLEH MAHASISWA PTKIN SE-SUMATERA BARAT
}

\author{
M. Imamuddin, Syahrul \& Raymond Dantes \\ IAIN Bukittinggi \\ Email: m.imamuddin76@yahoo.co.id
}

\begin{abstract}
Abstrak:
Islam mengajarkan umatnya untuk mengkonsumsi makanan dan minuman yang halal, suci dan baik. Mengkonsumsi makanan dan minuman yang halal, suci dan baik hukumnya wajib. Kehalalan terhadap suatu produk makanan dan minuman diwujudkan dalam bentuk sertifikasi halal dan tanda halal yang menyertai suatu produk. Penelitian ini bertujuan untuk menganalisis: 1. Pengaruh label halal terhadap keputusan pembelian, 2. Pengaruh religiusitas terhadap keputusan pembelian dan 3. Religiusitas dapat memperkuat/memperlemah pengaruh label halal terhadap keputusan pembelian produk kemasan. Penelitian ini merupakan penelitian kuantitatif. Populasi dalam penelitian ini adalah mahasiswa S1 PTKIN SeSumatera Barat. Sampel diambil 10\% dari masing-masing lembaga dengan total sampel 2782. Hasil penelitian memperoleh data tingkat religiusitas mahasiswa PTKIN se-Sumatera Barat berkategori tinggi dengan pengaruh label halal terhadap keputusan pembelian produk kemasan oleh mahasiswa sebesar $20.5 \%$, pengaruh religiusitas terhadap keputusan pembelian produk kemasan oleh mahasiswa sebesar $6.7 \%$ dan religiusitas memperkuat pengaruh label halal terhadap keputusan pembelian produk kemasan sebesar $2.3 \%$.
\end{abstract}

Kata Kunci: Label Halal, Moderasi, Religiusitas, Keputusan Pembelian dan Produ.

\begin{abstract}
:
Islam is used to consume food and beverages that are halal, holy and good. Consuming food and beverages that are lawful, sacred and good is obligatory. The halal of food and beverage products is realized in the form of halal certification and halal signs that accompany the product. This study aims to analyze: 1 . halal label labels on purchasing decisions, 2. Effect of religiosity on purchasing decisions and 3. Religiosity can improve from a package. This research is quantitative research. The Population in this study were PTKIN S1 students from West Sumatera. 5\% from each agency with a total sample of 2782 . The results of the study obtained data on the level of religiosity of PTKIN students throughout West Sumatra in a high category. Being influencing the halal label on packaging purchasing decisions by students is $20.5 \%$, the effect of prices on product packaging by students is $6.7 \%$ and religiosity on halal labels on the decision to purchase packaging products is $2.3 \%$.
\end{abstract}

Keywords: Halal, Moderation, Religiosity, Purchasing Decision Labels and Product 


\section{Pendahuluan}

Di Negara kita Indonesia, jaminan terhadap produk makanan dan minuman diwujudkan dalam bentuk sertifikasi halal dan tanda halal yang menyertai suatu produk. Tanda halal atau label halal tersebut dikeluarkan oleh Lembaga Pengkajian Pangan Obat-obatan dan Makanan Majelis Ulama Indonesia (LPPOM-MUI).

Dengan adanya label halal pada produk kemasan makanan dan minuman yang tertera pada kemasannya, akan berdampak positif bagi produk kemasan itu sendiri. Hal ini dapat dibuktikan dari hasil-hasil penelitian yang terkait dengan produk kemasan makanan yang berlabel halal, diantaranya hasil penelitian M. Imamuddin, yang menyimpulkan label halal berpengaruh signifikan terhadap keputusan pembelian. ${ }^{1}$ Sejalan dengan itu, hasil penelitian Eri dan Sujana, juga menyimpulkan labelisasi halal berkontribusi 49,7 \% dalam memutuskan untuk membeli barang. ${ }^{2}$ Begitu juga hasil penelitian Dewi \& Ilyda, hasil penelitian ini menyimpulkan labelisasi halal berpengaruh terhadap keputusan pembelian produk makanan impor kemasan. ${ }^{3}$

Tidak heran jika minat beli mahasiswa terhadap produk kemasan baik yang berupa makanan dan minuman sangat tinggi, hal ini dijumpai peneliti pada salahsatu mahasiswa di Perguruan Tinggi Keagamaan Islam Negeri (PTKIN) yang ada di Sumatera barat yaitu di IAIN Bukittinggi. Berdasarkan pra-survey peneliti pada tanggal 5 maret 2018 kepada 50 orang mahasiswa, diperoleh data 100\% mahasiswa sering membeli dan menkonsumsi produk kemasan makanan dan minuman. Adapun faktor-faktor mahasiswa mengkonsumsi produk kemasan adalah karena faktor kemudahan pengolahan 39.5\%, rasa 25.2\%, harga terjangkau $29.1 \%$, dan pengaruh teman 6.2\%. Berdasarkan data pra-survey tersebut, tidak ada mahasiswa yang memutuskan untuk membeli atau menkonsumsi produk kemasan makanan dan minuman karena faktor halal yang ditandai oleh adanya label halal yang terdapat pada kemasannya. Hal ini dapat disebabkan oleh pengetahuaan agama mahasiswa terkait tentang halal-haram dan lingkungan tempat tinggal.

Mahasiswa Perguruan Tinggi Keagamaan Islam Negeri (PTKIN) dipandang oleh masyarakat sebagai mahasiswa yang orentasinya mempelajari ilmu agama semata, sehingga memeliki religiusitas yang baik. Namun seiring dengan kemajuan zaman, PTKIN selain mencetak mahasiswa profesional dibidang agama juga mencetak mahasiswa profesional dibidang umum. Bidang pengetahuan umum yang ada di PTKIN tentunya masih tidak lepas dari pondasi dasar dari penyelenggaraan keilmuan di PTKIN yaitu ilmu-ilmu umum yang terintegrasi dan terkoneksi dengan ilmu-ilmu agama. Hal ini sejalan atau sesuai dengan masing-masing misi dan motto dari PTKIN yang ada terkhusus di sumatera barat. Misalnya misi UIN Imam Bonjol "Mengembangkan pola pemberdayaan masyarakat muslim". IAIN Batusangkar "Menghasilkan lulusan yang cerdas secara intelektual, spritual, emosional, sosial,

\footnotetext{
${ }^{1}$ M. Imamuddin. Pengaruh Label Halal dan Religiusitas terhadap Keputusan Pembelian Mie Instan Mahasiswa IAIN Bukittinggi T.A 2016/2017. EKONOMIKA SYARIAH: Journal of Economic Studies Vol. 1, No. 1, Januari-Juli 2017.

2 Eri Agustian H \& Sujana. Pengaruh Labelisasi Halal Terhadap Keputusan Pembelian Konsumen (Studi Kasus Pada Produk Wall's Conello). JIMKES Jurnal Ilmiah Manajemen Kesatuan Vol. 1 No. 2, 2013.

3 Dewi Kurnia Sari \& Ilyda Sudardjat, 2013. Analisis Pengaruh Labelisasi Halal Terhadap Keputusan Pembelian Produk Makanan Impor Dalam Kemasan Pada Mahasiswa Kedokteran Universitas Sumatera Utara. Jurnal Ekonomi dan Keuangan Vol. 1, No.4, Maret 2013.
} 
dan berdaya saing dalam dunia kerja. ${ }^{4}$ Dan motto IAIN Bukittinggi "Religius, Berbudaya dan Profesional". ${ }^{5}$ Berdasarkan misi dan motto PTKIN yang ada di Sumatera barat itu dapat disimpulkan, bahwa PTKIN Se-sumatera barat ingin mencetak mahasiswa yang profesional dalam bidangnya dan religiusitas yang tinggi.

Religiusitas menurut Glock dan Stark, merupakan "Sistem simbol, keyakinan, nilai, dan perilaku yang terlembagakan, dimana semuanya berpusat pada persoalanpersoalan yang dihayati sebagai yang paling maknawi". ${ }^{6}$ Religiusitas diwujudkan dalam segala aspek kehidupan, baik aktivitas yang nampak dan tidak nampak oleh mata serta yang ada dalam hati setiap individu. ${ }^{7}$ Dengan demikian dapat disimpulkan, religiusitas dapat diwujudkan dalam segala aktivitas kehidupan manusia termasuk juga dalam mengambil keputusan pembelian produk kemasan makanan dan minuman. ${ }^{8}$

Pentingnya Religiusitas, menyebabkan banyak peneliti melakukan penelitian terkait itu. Beberapa peneleliti diantaranya yang sudah melakukan penelitian terkait religiusitas adalah $\mathrm{M}$. Imamuddin, yang mana dalam penelitiannya menyimpulkan religiusitas berpengaruh signifikan terhadap keputusan pembelian. ${ }^{9}$ Berbeda dari hasil penelitian M. Imamuddin, Hasil penelitian Dwiwiyati Astogini, dkk, menyimpulkan religiusitas tidak berpengaruh terhadap keputusan pembelian produk halal. ${ }^{10}$ Jumani dan Siddiqui, melakukan penelitian terhadap 100 mahasiswa di Pakistan tentang Islamic Branding. Hasil Penelitiannya menyatakan bahwa persepsi sebagai variabel moderating lebih berpengaruh terhadap Islamic Branding daripada tingkat ketauhidan mereka. ${ }^{11}$ Moh. Fakhruddin dan Iva, dalam hasil penelitiannya menyimpulkan Religiousity commitment berpengaruh secara positif dan signifikan terhadap niat pembelian merk produk Islami. Dan Religiousity commitment tidak dapat diketahui dapat berperan sebagai variabel moderasi terhadap hubungan brand awreness terhadap niat pembelian merk produk Islami. ${ }^{12}$ Sedangkan Muhammad Nasrullah, hasil penelitiannya menyimpulkan Religiusitas sebagai variabel moderating memperlemah hubungan antara variabel Islamic branding dengan keputusan konsumen. ${ }^{13}$

\footnotetext{
4 http://www.kampusdunia.com/2017/03/akreditasi-jurusan-IAIN-Batusangkar.html.

5 Lembaga Penjamin Mutu (LPM) IAIN Bukittinggi, Kode Etik Dosen. (Bukittinggi: LPM, 2015), 7

${ }^{6}$ Ancok, Djamaludin dan Fuat Nasori Suroso. Psikologi Islami: Solusi Islam atas Problem-Problem Psikologi. Cetakan VIII. (Yogyakarta: Pustaka Pelajar, 2011), 76

7 Ancok, Djamaludin dan Fuat Nasori Suroso. Psikologi Islami: Solusi Islam atas Problem-Problem Psikologi. Cetakan VIII. (Yogyakarta: Pustaka Pelajar, 2011), 76

8 Moh Wardi. "Tradisi Ter-ater dan Dampak Ekonomi Bagi Masyarakat Madura." KARSA: Journal of Social and Islamic Culture 20.2 (2014): 40-57.

${ }^{9}$ M. Imamuddin. Pengaruh Label Halal dan Religiusitas terhadap Keputusan Pembelian Mie Instan Mahasiswa IAIN Bukittinggi T.A 2016/2017. EKONOMIKA SYARIAH: Journal of Economic Studies Vol. 1 , No. 1, Januari-Juli 2017

10 Dwiwiyati Astogini, dkk,. Aspek Religiusitas dalam Keputusan Pembelian Produk Halal. JEBA, Vol.13, No.1, Maret 2011

11 Jumani and Siddiqui. Bases of Islamic Branding In Pakistan: Perception or Believes. On Interdisclipinary Journal of Contemporary research in Business. Vol. 3. No. 9. 2012

12 Moh. Fakhruddin M dan Iva N, 2014. Religiousity Commitment Dalam Memoderasi Hubungan Brand Awareness Terhadap Niat Pembelian. Jurnal Modernisasi, Volume 10, Nomor 3, Oktober 2014

13 Muhammad Nasrullah. Islamic Branding, Religiusitas dan Keputusan Konsumen Terhadap Produk. Jurnal Hukum Islam (JHI), Volume 13, Nomor 2, Desember 2015
} 
Berdasarkan permasalahan dan penelitian terdahulu di atas yang menjadikan religiusitas sebagai variabel moderasi atau moderator dimana belum ada kejelasan apakah keputusan pembelian terhadap makanan atau minuman dipengaruhi oleh tingkat religiusitas. Oleh karena itu, peneliti tertarik untuk menganalisis hubungan religiusitas dalam memoderasi label halal terhadap keputusan pembelian makanan atau minuman dalam kemasan pada mahasiswa PTKIN Se-Sumatera Barat.

\section{Metode Penelitian}

Penelitian ini adalah penelitian kuantitatif dengan jenis penelitian korelasional (correlation research). Dikatakan berjenis penelitian korelasional sebab melihat hubungan antara variabel atau beberapa variabel dengan variabel lainnya. ${ }^{14}$ Populasi dalam penelitian ini adalah Mahasiswa S1 PTKIN Se-Sumatera Barat yang masih aktif pada Tahun Akademik 2018/2019. Populasi tersebar pada tiga PTKIN yaitu pada UIN Imam Bonjol, IAIN Bukittinggi dan IAIN Batusangkar. Jumlah mahasiswa tiga PTKIN dapat dijelaskan pada tabel berikut ini. ${ }^{15}$

\begin{tabular}{|l|l|c|}
\hline No & Instansi & Jumlah Mahasiswa \\
\hline 1 & UIN Imam Bonjol & 11.824 \\
\hline 2 & IAIN Bukittinggi & 8.916 \\
\hline 3 & IAIN Batusangkar & 7.078 \\
\hline \multicolumn{2}{c}{ Total } & 27.818 \\
\hline
\end{tabular}

Karena populasi pada penelitian ini berjumlah besar (27.818 mahasiswa), maka sampel dalam penelitian ini diambil 10\% dari masing-masing institusi. Sampel yang diambil sebanyak 2782 mahasiswa. Penentuan 2782 sampel penelitian ini, ditentukan dengan menggunakan accidental sampling (sampel aksidental). Sampel diambil berdasarkan kebetulan, tetapi objek yang diambil dapat diyakini sebagai sumber data. ${ }^{16}$ Sampel yang terpilih adalah mahasiswa yang mengkonsumsi produk kemasan yang berupa makanan dan minuman dalam seminggu terakhir dan tercatat sebagai mahasiswa aktif pada Tahun akademik 2018/2019.

Pengumpulan data dalam penelitian ini menggunakan angket. Angket yang digunakan dikembangkan berdasarkan kisi-kisi angket yang digunakan oleh M. Imamuddin, 2017. Kisi-kisi angket seperti yang terdapat pada tabel 1. berikut ini.

Tabel 1. Kisi-Kisi Angket

\begin{tabular}{|c|c|l|}
\hline No & Variabel & \multicolumn{1}{c|}{ Indikator } \\
\hline \multirow{4}{*}{1} & \multirow{4}{*}{ Label Halal (X) } & Proses Pembuatan \\
\cline { 3 - 3 } & & Bahan Baku Utama \\
\cline { 3 - 3 } & & Bahan Pembantu \\
\cline { 3 - 3 } 2 & \multirow{2}{*}{ Religiusitas (M) } & Efek \\
\cline { 3 - 3 } & & Syidah \\
\cline { 3 - 3 } & & Akhlak \\
\hline 3 & & Pengenalan kebutuhan \\
\hline
\end{tabular}

${ }^{14}$ Riyanto, Yatim, Metodologi Penelitian. (Surabaya: SIC, 2001), 34

${ }^{15}$ Informasi dari Akama UIN Imam bonjol, Akama IAIN Bukittinggi dan Akama IAIN Batusangkar

${ }_{16}$ Moh. Pabundu Tika. Metodologi Riset Bisnis. (Jakarta: Bumi Aksara, 2006), 48 


\begin{tabular}{|l|l|l|}
\hline \multirow{4}{*}{$\begin{array}{c}\text { Keputusan } \\
\text { Pembelian }(\mathrm{Y})\end{array}$} & Pencarian informasi \\
\cline { 3 - 3 } & & Evaluasi alternatif \\
\cline { 3 - 3 } & Keputusan pembelian \\
\cline { 3 - 3 } & Perilaku pasca pembelian \\
\hline
\end{tabular}

Sumber: M. Imamuddin, 2017.17

Sebelum digunakan dalam penelitian, instrumen yang dikembangkan terlebih dahulu diujicobakan kepada 100 mahasiswa S1 selain sampel penelitian, ujicoba instrument bertujuan untuk melihat tingkat validitas dan reabilitas dari instrumen. Uji validitas instrumen menggunakan rumus Product Moment Pearson yang dilakukan dengan cara mengkorelasikan skor jawaban yang diperoleh pada setiap item dengan skor total dari keseluruhan item instrumen, dan Uji reliabilitas dengan teknik Alpha Cronbach.

Untuk melakukan Uji hipotesis, terlebihdahulu dilakukan uji asumsi klasik yang meliputi; Uji normalitas, uji normalitas bertujuan untuk mengetahui model distribusi atau normal tidaknya sebaran data. Uji normalitas yang digunakan adalah tes Kolmogorov Smirnov. Uji Linearitas, uji linearitas bertujuan untuk mengetahui kelayakan variabel bebas dalam memprediksi variabel terikat. Uji linearitas yang digunakan adalah diagram pencar (scatter plot). Uji multikolinearitas, uji multikolinearitas bertujuan menguji model regresi, jika terjadi korelasi antar variabel independen maka terdapat problem multikolinearitas/multiko. Pengambilan keputusan dengan melihat nilai toleran dan Variance Inflation Factor (VIF), apabila nilai tolerance value lebih besar dari 0,1 dan nilai Variance Inflation Factor (VIF) kurang dari 10 maka tidak terjadi multikolinierasi. ${ }^{18}$ Uji Autokorelasi, uji Autokorelasi bertujuan untuk mengetahui korelasi antar variabel. Uji yang digunakan adalah uji Durbin-Watson (D-W), dengan ketentuan jika angka D-W di antara -2 sampai +2 berarti tidak ada autokorelasi dan autokorelasi negatif jika angka D-W di atas +2 .

Uji hipotesis dilakukan dengan uji statistik inferensial, statistik inferensial yang digunakan dalam penelitian ini adalah analisis regresi linear sederhana (simple linear regression) dan Moderated Regression Analysis (MRA). Analisis regresi linear sederhana digunakan untuk melihat hubungan atau pengaruh secara parsial (tunggal) antara masing-masing variabel bebas (independent variabel) yaitu label halal $(\mathrm{X})$ dan variabel moderator (moderating variabel) yaitu religiusitas (M) terhadap variabel terikat (dependent variabel) yaitu keputusan pembelian (Y). Sedangkan untuk menganalisis variabel moderator (religiusitas) memperkuat atau memperlemah pengaruh label halal terhadap keputusan pembelian digunakan Moderated Regression Analysis (MRA). Moderated Regression Analysis (MRA) atau uji interaksi merupakan aplikasi khusus regresi berganda linear dimana dalam

17 M. Imamuddin. Pengaruh Label halal dan Religiusitas terhadap Keputusan Pembelian Mie Instan Oleh Mahasiswa IAIN Bukittinggi T.A 2016/2017. EKONOMIKA SYARIAH: Journal of Economic Studies Vol. 1 , No. 1, Januari-Juli 2017

18 Nawari, Analisis Regresi dengan MS Exel 2007 dan SPSS 17, (Jakarta: PT Elek Media Komputindo, 2010), 243 
persamaan regresinya mengandung unsur interaksi (perkalian dua atau lebih variabel independen). ${ }^{19}$ Rumus persamaan sebagai berikut:

$$
\mathrm{Y}=\mathrm{a}_{0}+\mathrm{a}_{1} \mathrm{X}+\mathrm{a}_{2} \mathrm{M}+\mathrm{a}_{3} \mathrm{XM}+\mathrm{e}
$$

Keterangan:

$$
\begin{array}{ll}
\mathrm{Y} & \text { : Keputusan Pembelian } \\
\text { a0 } & \text { : Konstanta } \\
\mathrm{X} & \text { : Label Halal } \\
\mathrm{M} & \text { : Religiusitas } \\
\mathrm{XM} & \text { : Label Halal } X \text { Religiusitas } \\
\mathrm{e} & \text { : Residu/sisa } \\
\text { a1-3 } & \text { : Koefisien regresi untuk masing-masing variabel. }
\end{array}
$$

Variabel perkalian antara X dan $\mathrm{M}$ disebut juga variabel moderat oleh karena menggambarkan pengaruh moderating variabel $\mathrm{M}$ terhadap hubungan $\mathrm{X}$ dan $\mathrm{Y}$. Dalam penelitian ini, proses pengujian/analisis data menggunakan program SPSS for windows versi 16.00 .

\section{Pembahasan Dan Hasil Penelitian}

Sebelum angket digunakan dalam penelitian, Angket diujicobakan kepada 100 responden untuk mengetahui tingkat validitas dan relibilitas angket. Hasil uji validitas angket dengan menggunakan rumus Product Moment Pearson diperoleh $r_{\text {hitung }}>r_{\text {tabel }}=0.195$, sehingga semua soal valid. Sedangkan untuk reabilitas diperoleh nilai Cronbach's Alpha sebesar 0.849, karena nilai Cronbach's Alpha $\geq 0.60$ maka semua soal reliabel. Berdasarkan uji validitas dan reliabelitas angket dapat digunakan dalam penelitian.

Deskripsi statistik hasil penelitian kepada 2782 sampel disajikan dalam tabel 2 berikut:

Tabel 2. Statistik Deskriptif Sampel

\begin{tabular}{|l|r|c|c|c|c|}
\hline & $\mathrm{N}$ & Minimum & Maximum & Mean & $\begin{array}{c}\text { Std. } \\
\text { Deviation }\end{array}$ \\
\hline Label Halal & 278 & 4 & 27.00 & 19.2257 & 4.34821 \\
& 2 & & & & \\
Religiusitas & 278 & 3 & 27.00 & 24.1923 & 2.85576 \\
Keputusan & 278 & 1 & 15.00 & 9.6991 & 2.65269 \\
Pembelian & 2 & 1 & & & \\
Valid N (listwise) & 278 & & & & \\
\hline
\end{tabular}

Berdasarkan tabel 2. di atas, dibuatlah kategori religiusitas mahasiswa dengan kategori tinggi, sedang, rendah dengan rentang nilai seperti berikut :

\footnotetext{
${ }^{19}$ Liana, Lie, Penggunaan MRA dengan Spss untuk Menguji Pengaruh Variabel Moderating terhadap Hubungan antara Variabel Independen dan Variabel Dependen, Jurnal Teknologi Informasi DINAMIK Volume XIV, No.2, Juli 2009
} 
1. Nilai 19 - 27 katagori tinggi

2. Nilai $11-19$ katagori sedang

3. Nilai 3 - 11 katagori rendah.

Berdasarkan tabel 2 di atas, diperoleh rata-rata religiusitas mahasiswa adalah 24.1923. Dengan merujuk kategori di atas, maka religiusitas mahasiswa PTKIN Se-Sumatera Barat Tahun Akademik 2018/2019 dapat digolongkan dalam kategori tinggi.

Sedangkan hasil uji asumsi klasik diperoleh; Normalitas data dengan menggunakan uji Kolmogorov-Smirnov (K-S), nilai Asymp. Sig (2-tailed) sebesar 0.103 , nilai ini berada jauh di atas $\alpha=0.05$ (Asymp. Sig (2-tailed) $>\alpha=0.05$ ) dengan demikian dapat disimpulkan data berdistribusi normal. Untuk linearitas label halal terhadap keputusan diperoleh $\mathrm{F}_{\text {hitung }}=761.993$ dan sig $=0.00$. Sedangkan $\mathrm{F}_{\text {tabel }}=$ 3.84, Karena Fhitung $>F_{\text {tabel }}$ dan sig $<0.05$, maka data berpola linier dan signifikan. Linieritas data religiusitas terhadap data keputusan pembelian diperoleh $\mathrm{F}_{\text {hitung }}=$ 206.639 dan sig $=0.00$. sedangkan $F_{\text {tabel }}=3.84$. Karena $F_{\text {hitung }}>F_{\text {tabel }}$ dan $\operatorname{sig}<0.05$, maka data berpola linier dan signifikan. Sedangkan linieritas Label halal X Religiusitas terhadap data keputusan pembelian memperoleh $F_{\text {hitung }}=910.411$ dan $\operatorname{sig}=0.00$. sedangkan $F_{\text {tabel }}=3.84$. Karena $F_{\text {hitung }}>F_{\text {tabel }}$ dan $\operatorname{sig}<0.05$, maka data berpola linier dan signifikan.

Hasil Uji Multikolinearitas disajikan pada tabel 3 berikut.

Tabel 3. Hasil Uji Multikolinearitas

Coefficients ${ }^{3}$

\begin{tabular}{|c|c|c|c|c|c|c|c|c|}
\hline \multirow{2}{*}{\multicolumn{2}{|c|}{ Model }} & \multicolumn{2}{|c|}{ Unstandardized Coefficients } & \multirow{2}{*}{$\begin{array}{c}\begin{array}{c}\text { Standardized } \\
\text { Coefficients }\end{array} \\
\text { Beta }\end{array}$} & \multirow[b]{2}{*}{$t$} & \multirow[b]{2}{*}{ Siq. } & \multicolumn{2}{|c|}{ Collinearity Statistics } \\
\hline & & B & Std. Error & & & & Tolerance & VIF \\
\hline \multirow[t]{4}{*}{1} & (Constant) & 4.033 & .975 & & 4.135 & .000 & & \\
\hline & Label Halal & .089 & .057 & .146 & 1.572 & .116 & .321 & 1.201 \\
\hline & Religiusitas & .034 & .040 & .036 & .839 & .401 & .146 & 6.756 \\
\hline & Label Halal X Religiusitas & .007 & .002 & .321 & 2.925 & .003 & .116 & 3.532 \\
\hline
\end{tabular}

a. Dependent Variable: Keputusan Pembelian

Berdasarkan tabel 3 di atas, diperoleh nilai dari tolerance value $>0.100$ dan nilai VIF semua variabel < 10, sehingga disimpulkan tidak terjadi multikolinearitas. Sedangkan hasil uji Autokorelasi dengan menggunakan uji Durbin-Watson (D-W). Nilai D-W berdasarkan perhitungan dapat dilihat pada tabel 4 berikut:

Tabel 4. Nilai D-W sebagai Dasar Uji Autokorelasi

Model Summary ${ }^{\mathrm{b}}$

\begin{tabular}{|l|l|r|r|r|r|}
\hline $\begin{array}{l}\text { Mode } \\
\perp\end{array}$ & $\mathrm{R}$ & $\mathrm{R}$ Square & $\begin{array}{c}\text { Adjusted R } \\
\text { Square }\end{array}$ & $\begin{array}{c}\text { Std. Error of } \\
\text { the Estimate }\end{array}$ & $\begin{array}{c}\text { Durbin- } \\
\text { Watson }\end{array}$ \\
\hline 1 & $.479 \mathrm{~g}$ & .229 & .228 & 2.33024 & 1.719 \\
\hline
\end{tabular}

a. Predictors: (Constant), Label Halal X Religiusitas, Religiusitas, Label Halal

b. Dependent Variable: Keputusan Pembelian 
Berdasarkan tabel 4. di atas, nilai D - W adalah 1.719 berada diantara $-2<$ $1.719<+2$. sehingga disimpulkan tidak terjadi Autokorelasi. Uji hipotesis dalam penelitian ini dengan menggunakan metode regresi linear sederhana dan metode Moderate Regression Analysis (MRA). Hasil pengujian regresi linear sederhana pengaruh label halal terhadap keputusan pembelian dapat dituliskan dalam persamaan regresi $\mathbf{Y}=\mathbf{4 . 3 8 8}+\mathbf{0 . 2 7 6 X}$. Sedangkan pengaruh signifikan label halal terhadap keputusan pembelian dapat dilihat dari nilai thitung $=26.780$ dan tabel $=$ 1.653 dengan nilai thitung $>$ tabel. Sedangkan nilai sig $=0.000<\alpha=0.05$.

Sedangkan hubungan variabel moderasi M (religiusitas) terhadap variabel $Y$ (Keputusan pembelian) dapat dituliskan dalam persamaan regresi $\mathbf{Y}=\mathbf{3 . 8 8 7}+$ 0.240 M. Sedangkan signifikansi religiusitas terhadap keputusan pembelian dapat dilihat dari nilai thitung $=14.118$ dan $t_{\text {tabel }}=1.653$ berarti nilai $t_{h i t u n g}>t_{\text {tabel }}$. Sedangkan nilai sig $=0.000<\alpha=0.005$.

Sedangkan hasil uji MRA dapat dilihat dalam tabel 5 berikut.

Tabel 5. Moderate Regression Analysis (MRA)

\section{Coefficients $^{\mathrm{a}}$}

\begin{tabular}{|l|r|r|r|r|r|}
\hline \multirow{2}{*}{ Model } & \multicolumn{2}{|c|}{$\begin{array}{c}\text { Unstandardized } \\
\text { Coefficients }\end{array}$} & $\begin{array}{c}\text { Standardized } \\
\text { Coefficients }\end{array}$ & & \\
\cline { 2 - 5 } & \multicolumn{1}{|c|}{$\mathrm{B}$} & Std. Error & \multicolumn{1}{c|}{ Beta } & \multicolumn{1}{c|}{$\mathrm{t}$} & Sig. \\
\hline $1 \quad$ (Constant) & 4.033 & .975 & & 4.135 & .000 \\
Religiusitas & .034 & .040 & .036 & .839 & .401 \\
Label Halal & .089 & .057 & .146 & 1.572 & .116 \\
Label Halal X & .007 & .002 & .321 & 2.925 & .003 \\
Religiusitas & & & & \\
\hline
\end{tabular}

a. Dependent Variable: Keputusan Pembelian

Dari tabel 5 di atas, dapat dibuat persamaan regresinya $\mathbf{Y}=\mathbf{4 . 0 3 3}+\mathbf{0 . 0 8 9 X}$ + 0.034M + 0.007 XM. Dan hasil analisis sampel dengan menggunakan uji F di sajikan pada tabel 4.6 berikut.

Tabel 6. Hasil Uji F

\begin{tabular}{|c|c|c|c|c|c|c|}
\hline \multicolumn{7}{|c|}{ ANOVA $^{b}$} \\
\hline \multicolumn{2}{|c|}{ Model } & Sum of Squares & Df & $\begin{array}{c}\text { Mean } \\
\text { Square }\end{array}$ & $\mathrm{F}$ & Sig. \\
\hline 1 & Regression & 4484.626 & 3 & 1494.875 & 275.299 & $.000^{\mathrm{a}}$ \\
\hline & Residual & 15084.552 & 2778 & 5.430 & & \\
\hline & Total & 19569.178 & 2781 & & & \\
\hline
\end{tabular}

a. Predictors: (Constant), Label Halal X Religiusitas, Religiusitas, Label Halal

b. Dependent Variable: Keputusan Pembelian 
Berdasarkan tabel 6 di atas, diperoleh nilai $F_{\text {hitung }}=275.299$ dengan nilai probabilitas $(\mathrm{sig})=0.000$ dan $\mathrm{F}_{\text {tabel }}=2.60$. Karena nilai $\mathrm{F}_{\text {hitung }}>\mathrm{F}_{\text {tabel }}$ dan nilai sig $<$ 0.05, maka dapat disimpulkan Ho ditolak artinya $\mathrm{H}_{1}$ diterima yaitu Religiusitas sebagai variabel moderasi dapat memperkuat pengaruh Label halal terhadap keputusan pembelian produk kemasan oleh Mahasiswa PTKIN Se-Sumatera Barat.

Berdasarkan analisis deskriptif, diperoleh rata-rata untuk semua variabel yang diteliti. Rata-rata variabel label halal sebesar 19.23 dan rata-rata variabel religiusitas sebesar 24.20. Berdasarkan dari rata-rata religiusitas mahasiswa tersebut, maka religiusitas mahasiswa PTKIN Se-Sumatera Barat Tahun Akademik 2018/2019 tergolong tinggi. Sedangkan berdasarkan pengujian regresi menunjukkan hipotesis pertama diterima yaitu variabel label halal berpengaruh positif dan signifikan terhadap keputusan pembelian produk kemasan oleh mahasiswa PTKIN Se-Sumatera Barat, hal ini ditunjukkan dengan nilai thitung = $26.780>t_{\text {tabel }}=1.653$ dan siginifikan $0.000<\alpha=0.05$. Sedangkan nilai koefisien label halal pada persamaan regresi bernilai positif yaitu sebesar 0.267 yang berarti bahwa semakin tinggi tingkat label halal maka keputusan terhadap pembelian produk kemasan juga akan semakin meningkat.

Pengaruh label halal terhadap keputusan pembelian produk kemasan oleh mahasiswa sebesar 20.5\%. Hal ini sejalan dengan hasil penelitian Eri dan Sujana yaitu labelisasi halal memiliki kontribusi sebesar $49.7 \%$ dalam menciptakan keputusan pembelian. ${ }^{20}$ Hasil penelitian Yuli Mutia Rambe dan Syaad Afifuddin yang menyatakan label halal memberikan pengaruh sebesar $31.1 \%$ terhadap minat beli. ${ }^{21}$ Dan hasil penelitian M. Imamuddin dimana label halal memberikan pengaruh terhadap keputusan pembelian mie Instan sebesar $18.2 \%{ }^{22}$

Bagi umat muslim label halal merupakan hal yang perlu diperhatikan sebelum adanya keputusan pembelian. Hal ini sejalan dengan hasil penelitian yang dilakukan oleh Ady Syahputra dan Haroni Doli Hamoraon yang menyatakan umat muslim di kecamatan perbaungan setuju kalau dengan adanya label halal yang tertera di dalam kemasan menjadi salah satu faktor minat beli konsumen. ${ }^{23}$ Karena dalam membeli atau mengkonsumsi suatu produk atau barang konsumen tidak menentang syariat Islam sehingga kehalalan suatu produk barang yang dibeli harus diperhatikan. Dalam Islam juga diajarkan mengenai halal dan haram, sebagaimana dijelaskan dalam Al-quran yang artinya: Maka makanlah yang halal lagi baik dari rezki yang telah diberikan Allah kepadamu; dan syukurilah nikmat Allah, jika kamu hanya kepada-Nya saja menyembah. (Q.S An-Nahl : 114).

20 Eri Agustian H \& Sujana. Pengaruh Labelisasi Halal Terhadap Keputusan Pembelian Konsumen (Studi Kasus Pada Produk Wall's Conello). JIMKES Jurnal Ilmiah Manajemen Kesatuan Vol. 1 No. 2, 2013

21 Yuli Mutiah Rambe \& Syaad Afifuddin. Pengaruh Pencantuman Label Halal pada Kemasan Mie Instan Terhadap minat Pembelian Masyarakat Muslim. Jurnal Ekonomi dan Keuangan, Vol. 1, No. 1, Desember 2012

22 M. Imamuddin. Pengaruh Label Halal dan Religiusitas terhadap Keputusan Pembelian Mie Instan Mahasiswa IAIN Bukittinggi T.A 2016/2017. EKONOMIKA SYARIAH: Journal of Economic Studies Vol. 1 , No. 1, Januari-Juli 2017

23 Ady Syahputra \& Haroni Doli Hamoraon. Pengaruh Labelisasi Halal Terhadap Keputusan Masyarakat Kecamatan Perbaungan dalam Pembelian Produk Makanan dalam Kemasan. Jurnal Ekonomi dan Keuangan Vol. 2, No.8, 2014 
Berdasarkan ayat di atas, telah dijelaskan bahwa umat Islam diperintahkan untuk memakan yang halal (diperbolehkan) dan bersyukur atas nikmat yang diberikan Allah SWT. Dengan demikian label halal menjadi penting karena merupakan anjuran syariat Islam, sehingga sangat berpengaruh pada keputusan pembelian produk dan jasa.

Dengan demikian, adanya label halal pada produk kemasan sangat positif dan sangat menguntungkan bagi produsen produk kemasan. Label halal dapat memberikan pengaruh terhadap keputusan pembelian konsumen terutama konsumen muslim, sehingga pada akhirnya dapat meningkatkan daya produksi dari produk kemasan.

Berdasarkan analisis deskriptif rata-rata religiusitas adalah 24.20, dengan demikian religiusitas mahasiswa PTKIN Se-sumatera Barat Tahun Akademik 2018/2019 termasuk ke dalam kategori tinggi. Sedangkan berdasarkan pengujian regresi menunjukkan hipotesis kedua diterima yaitu variabel religiusitas berpengaruh positif dan signifikan terhadap keputusan pembelian produk kemasan oleh mahasiswa PTKIN Se-Sumatera Barat, hal ini ditunjukkan dengan nilai thitung = $14.118>t_{\text {tabel }}=1.653$ dan siginifikan $0.000<\alpha=0.05$. Sedangkan nilai koefisien religiusitas pada persamaan regresi bernilai positif yaitu sebesar 0.240 yang berarti bahwa semakin tinggi tingkat religiusitas mahasiswa maka keputusan terhadap pembelian produk kemasan juga akan semakin meningkat.

Pengaruh religiusitas terhadap keputusan pembelian produk kemasan oleh mahasiswa sebesar 6.7\%. Sejalan dangan hasil penelitian Moh. Fakhruddin M dan Iva $\mathrm{N}$ menyatakan Relgiousity commitment berpengaruh secara positif dan signifikan terhadap niat pembelian merk produk islami. ${ }^{24} \mathrm{Hal}$ ini juga sejalan dengan hasil penelitian Anton Bawono yang menyatakan religiusitas memiliki kontribusi besar dalam mempengaruhi keputusan konsumsi. ${ }^{25}$ Dan penelitian M. Imamuddin menyimpulkan religiusitas berpengaruh sebesar $4.2 \%$ terhadap keputusan pembelian mie instan. ${ }^{26}$ Hasil penelitian ini, berbeda dengan hasil penelitian Dwiwiyati Astogini, Wahyudin dan Siti Zulaikha Wulandari yang menyatakan religiusitas tidak berpengaruh terhadap keputusan pembelian produk halal. ${ }^{27}$

Dengan demikian religiusitas mahasiswa PTKIN Se-sumatera Barat memberikan kontribusi terhadap keputusan pembelian produk halal. Hal ini mencerminkan kualitas religiusitas mahasiswa tercermin dalam aktivitas seharihari. Hal ini sejalan dengan yang dikemukakan Ancok, Religiusitas diwujudkan

\footnotetext{
${ }^{24}$ Moh. Fakhruddin M dan Iva N,. Religiousity Commitment Dalam Memoderasi Hubungan Brand Awareness Terhadap Niat Pembelian. Jurnal Modernisasi, Volume 10, Nomor 3, Oktober 2014

25 Anton Bawono. Kontribusi Religiusitas dalam Perilaku Pengambilan Keputusan Konsumsi. Jurnal Muqtasid Volume 2 Nomor 1, Juni 2011

${ }^{26}$ M. Imamuddin. Pengaruh Label Halal dan Religiusitas terhadap Keputusan Pembelian Mie Instan Mahasiswa IAIN Bukittinggi T.A 2016/2017. EKONOMIKA SYARIAH: Journal of Economic Studies Vol. 1 , No. 1, Januari-Juli 2017

${ }^{27}$ Dwiwiyati Astogini, dkk,. Aspek Religiusitas dalam Keputusan Pembelian Produk Halal. JEBA, Vol.13, No.1, Maret 2011
} 
dalam berbagai sisi kehidupan berupa aktivitas yang tampak dan dapat dilihat oleh mata, serta aktivitas yang tidak tampak yang terjadi dalam hati seseorang. ${ }^{28}$

Untuk menganalisis interaksi religiusitas terhadap label halal, maka dilakukan pengujian dengan menggunakan Moderat Regresi Analisis (MRA). Variabel moderating (XM) memiliki nilai koefisien sebesar 0.007 dengan probabilitas signifikansi sebesar 0.003 (sig < 0.05 ) dan memberikan pengaruh sebesar $22.8 \%$. Ketika secara parsial label halal mempengaruhi keputusan pembelian produk kemasan hanya sebesar 20.5\%. Dan setelah diinteraksikan dengan religiusitas pengaruhnya berubah menjadi $22.8 \%$, artinya ada peningkatan pengaruh terhadap keputusan pembelian produk kemasan sebesar $2.3 \%$ setelah diinteraksikan dengan religiusitas.

Temuan ini menunjukkan religiusitas memperkuat pengaruh label halal terhadap keputusan pembelian produk kemasan. Temuan ini, berbeda dengan hasil penelitian Moh. Fakhruddin dan Ivan yang menyatakan religiousity commitment tidak dapat diketahui dapat berperan sebagai variabel moderasi terhadap hubungan brand awreness terhadap niat pembelian merk produk Islami. ${ }^{29}$ Dan hasil penelitian Muhammad Nasrullah menyatakan religiusitas sebagai variabel moderating memperlemah hubungan antara variabel Islamic branding dengan keputusan konsumen. ${ }^{30}$

\section{Penutup}

Mahasiswa PTKIN Se-Sumatera Barat dikategorikan memiliki tingkat religiusitasnya tinggi. Sedangkan Pengaruh label halal terhadap keputusan pembelian produk kemasan sebesar 20.5\%, Pengaruh religiusitas terhadap keputusan pembelian produk kemasan sebesar 6.7\% dan religiusitas memperkuat pengaruh label halal terhadap keputusan pembelian produk kemasan sebesar $2.3 \%$. Dengan demikian umat Islam harus mempunyai literasi terhadap makanan kemasan agar tidak terjebak dengan makanan dan minuman kemasan yang belum diketahui kehalalannya.

Penelitian selanjutnya disarankan untuk menggunakan variabel moderasi religiusitas digunakan dalam penelitian yang lebih luas.

\section{Daftar Pustaka}

Ady Syahputra \& Haroni Doli Hamoraon. Pengaruh Labelisasi Halal Terhadap Keputusan Masyarakat Kecamatan Perbaungan dalam Pembelian Produk Makanan dalam Kemasan. Jurnal Ekonomi dan Keuangan Vol. 2, No.8, 2014

Ancok, Djamaludin dan Fuat Nasori Suroso, Psikologi Islami: Solusi Islam atas Problem-Problem Psikologi. Cetakan VIII. (Yogyakarta: Pustaka Pelajar, 2011)

Anton Bawono. Kontribusi Religiusitas dalam Perilaku Pengambilan Keputusan Konsumsi. Jurnal Muqtasid Volume 2 Nomor 1, Juni 2011.

\footnotetext{
28 Ancok, Djamaludin dan Fuat Nasori Suroso, Psikologi Islami: Solusi Islam atas Problem-Problem Psikologi. Cetakan VIII. (Yogyakarta: Pustaka Pelajar, 2011), 76

29 Moh. Fakhruddin M dan Iva N,. Religiousity Commitment Dalam Memoderasi Hubungan Brand Awareness Terhadap Niat Pembelian. Jurnal Modernisasi, Volume 10, Nomor 3, Oktober 2014 ${ }^{30}$ Muhammad Nasrullah. Islamic Branding, Religiusitas dan Keputusan Konsumen Terhadap Produk. Jurnal Hukum Islam (JHI), Volume 13, Nomor 2, Desember 2015
} 
Dewi Kurnia Sari \& Ilyda Sudardjat, 2013. Analisis Pengaruh Labelisasi Halal Terhadap Keputusan Pembelian Produk Makanan Impor Dalam Kemasan Pada Mahasiswa Kedokteran Universitas Sumatera Utara. Jurnal Ekonomi dan Keuangan Vol. 1, No.4, Maret 2013

Dwiwiyati Astogini, dkk,. Aspek Religiusitas dalam Keputusan Pembelian Produk Halal. JEBA, Vol.13, No.1, Maret 2011.

Eri Agustian H \& Sujana. Pengaruh Labelisasi Halal Terhadap Keputusan Pembelian Konsumen (Studi Kasus Pada Produk Wall's Conello). JIMKES Jurnal Ilmiah Manajemen Kesatuan Vol. 1 No. 2, 2013

http://www.kampusdunia.com/2017/03/akreditasi-jurusan-IAINBatusangkar.html

Jumani and Siddiqui. Bases of Islamic Branding In Pakistan: Perception or Believes. On Interdisclipinary Journal of Contemporary research in Business. Vol. 3. No. 9. 2012.

Lembaga Penjamin Mutu (LPM) IAIN Bukittinggi, Kode Etik Dosen. (Bukittinggi: LPM, 2015)

Liana, Lie, Penggunaan MRA dengan Spss untuk Menguji Pengaruh Variabel Moderating terhadap Hubungan antara Variabel Independen dan Variabel Dependen, Jurnal Teknologi Informasi DINAMIK Volume XIV, No.2, Juli 2009

M. Imamuddin, Pengaruh Label Halal dan Religiusitas terhadap Keputusan Pembelian Mie Instan Mahasiswa IAIN Bukittinggi T.A 2016/2017. EKONOMIKA SYARIAH: Journal of Economic Studies Vol. 1 , No. 1, Januari-Juli 2017, DOI : 10.30983/es.v1i1.448

Moh. Fakhruddin M dan Iva N,. Religiousity Commitment Dalam Memoderasi Hubungan Brand Awareness Terhadap Niat Pembelian. Jurnal Modernisasi, Volume 10, Nomor 3, Oktober 2014.

Moh. Pabundu Tika, Metodologi Riset Bisnis. (Jakarta: Bumi Aksara, 2006)

Moh Wardi. "Tradisi Ter-ater dan Dampak Ekonomi Bagi Masyarakat Madura." KARSA: Journal of Social and Islamic Culture 20.2 (2014): 40-57.

Muhammad Nasrullah, Islamic Branding, Religiusitas dan Keputusan Konsumen Terhadap Produk. Jurnal Hukum Islam (JHI), Volume 13, Nomor 2, Desember 2015

Nawari, Analisis Regresi dengan MS Exel 2007 dan SPSS 17.( Jakarta: PT Elek Media Komputindo, 2010)

Riyanto, Yatim, Metodologi Penelitian. (Surabaya: SIC, 2001)

Yuli Mutiah Rambe \& Syaad Afifuddin. Pengaruh Pencantuman Label Halal pada Kemasan Mie Instan Terhadap minat Pembelian Masyarakat Muslim. Jurnal Ekonomi dan Keuangan, Vol. 1, No. 1, Desember 2012. 